\title{
Hydrogeomorphic Characteristics of Urban Flood Triggers in Gombe Town, Nigeria as Monitored in 2014
}

\author{
${ }^{1}$ ABASHIYA, M; *2 ABAJE, IB; ${ }^{1}$ MUSA, I; ${ }^{1}$ SULE, S; ${ }^{1}$ KOLLOS, PN; ${ }^{3}$ GARBA, HA \\ ${ }^{*}$ Department of Geography, Gombe State University, Gombe, Nigeria \\ ${ }^{2}$ Department of Geography and Regional Planning, Federal University, Dutsin-Ma, Nigeria. \\ ${ }^{3}$ Department of Geography, Taraba State University, P.M.B. 1167, Jalingo, Nigeria \\ *Corresponding Author Email: E-mail: abajebest@gmail.com; Tel: +2348036642086, +2348027942167
}

\begin{abstract}
$\boldsymbol{A B S T R A C T :}$ : Urban flooding has become a monumental yearly disaster in many of the world's cities and Gombe town in particular. This paper focused on some hydro-geomorphological characteristics that influence flooding in Gombe town. Statistical methods and geographic information techniques were used for the assessment. The result revealed that the highest API of $166.62 \mathrm{~mm}$ occurred on the 5/9/2014. The rainfall amount was $92.5 \mathrm{~mm}$ for a duration 48 minutes, average rainfall intensity was 115.63 , stage height $(1.42 \mathrm{~m})$, average flow velocity $(0.98 \mathrm{~m} / \mathrm{s})$, and instantaneous discharge of $9.47 \mathrm{~m}^{3} / \mathrm{s}$. This corresponds with the flood disaster that occurred in Gombe town on the same date $(5 / 9 / 2014)$. On the other hand, the least API of $18.12 \mathrm{~mm}$ occurred on the 18/6/2014. The rainfall amount was $1.2 \mathrm{~mm}$ for 62 minutes, average rainfall intensity was 1.16 , stage height $(0.30 \mathrm{~m})$, average flow velocity $(0.24 \mathrm{~m} / \mathrm{s})$, and instantaneous discharge of $0.49 \mathrm{~m}^{3} / \mathrm{s}$. findings also showed that very steep slope covered $2.4537 \mathrm{~km}^{2}(1.78 \%)$, steep slope covered $3.60235 \mathrm{~km}^{2}(2.61 \%)$, moderate slope $\left(0.735574 \mathrm{~km}^{2}\right.$ or $\left.0.53 \%\right)$, gentle slope $\left(131.106 \mathrm{~km}^{2}\right.$ or $\left.94.89 \%\right)$ and flat areas $\left(0.259854 \mathrm{~km}^{2}\right.$ or $\left.0.19 \%\right)$. The study recommended flood resilience technology, provision of adequate urban drainages and proper storm water management.
\end{abstract}

\section{DOI: https://dx.doi.org/10.4314/jasem.v23i10.19}

Copyright: Copyright (C) 2019 Abashiya et al. This is an open access article distributed under the Creative Commons Attribution License (CCL), which permits unrestricted use, distribution, and reproduction in any medium, provided the original work is properly cited.

Dates: Received: 01 September 2019; Revised: 21 October 2019; 27 October 2019

Keywords: Drainage density, flow accumulation, rainfall, urban flooding

Flooding from time immemorial has been the most common and wide spread of both natural and manmade hazards that have unleashed untold fear and hardship on mankind. There are a number of hydrological and geomorphological factors that affect the severity of flood hazard including Antecedent Precipitation Index (API), drainage density, rainfall amount, duration and intensity, stage height, flow velocity and topographic characteristics of the drainage basin. API expresses the moisture condition of the area prior to storm runoff. It is a reliable conventionally accepted index which is crucial in hydro-geomorphological studies and it is considered as the most important soil factor for rapid runoff and flooding (Goudie, 2006; Abaje et al., 2015). Saturated soils obstruct rainfall to infiltrate, resulting in higher runoff regardless of other environmental conditions. Soil moisture can, in fact, control whether a given rainstorm produces a major flood or not due to the nonlinear nature of runoff response to rainfall. The drainage pattern of a place plays a major role in assessing hydrological conditions and hence enhances the understanding of urban flood assessment (Abaje et al., 2012). Urban flooding occurs in response to intense rainfall which overwhelms natural or manmade inadequate drainage systems resulting in water flowing overland and ponding in depressions. It is a particular problem in urban areas which are often dominated by impermeable surfaces. The global warming and its effects on climate has increased precipitation and runoff particularly in urban areas leading to environmental hazard such as flooding (Abaje et al., 2016; Abaje et al., 2017). The projection of climate change trends as stated in IPCC (2013) indicates increase in the occurrence of rainfall events both in terms of their intensities as well as frequencies. Such high intensity rainfall events along with the changes in land use patterns, particularly in urbanized areas are expected to have implications on urban flooding (Duan, et al, 2016). Recent studies show that contemporary urban areas in developing countries are vulnerable to weather and climate related hazard events such as flooding (Abaje, et al, 2017). Anthropogenic activities in the urban environment can enhance the occurrence of flooding. The effectiveness and efficiency of urban drainages rely solely on their ability to evacuate excess runoff to prevent flooding. In urban areas where drainages are inadequate or 
poorly constructed the resultant effect is frequent flooding (Abashiya, 2006). In Gombe town, the drains are either shallow or clogged with refuse dump and are often undermined by excess runoff. The main objective of this paper, therefore, is to examine some hydro-geomorphological characteristics that influence flooding in Gombe town as monitored in 2014.

\section{MATERIALS AND METHODS}

Description of Study Area: Gombe town is located between latitudes $10^{\circ} 14^{\prime} 10^{\prime \prime} \mathrm{N}$ and $10^{\circ} 19^{\prime} 00^{\prime \prime} \mathrm{N}$ of the equator and between Longitudes $11^{\circ} 07^{\prime} 00^{\prime \prime} \mathrm{E}$ and $11^{\circ} 12^{\prime} 50^{\prime \prime} \mathrm{E}$ of the Greenwich Meridian. It is bounded by Kwami LGA to the North, Akko LGA to the Southwest and Yamaltu-Deba LGA to the East as shown in Figure 1. Gombe town has a tropical continental type of climate (Aw) based on Koppen's classification scheme. It is characterized by strong rainfall seasonality with distinct wet and dry season (Abaje et al, 2017). The rainfall is concentrated between the months of July and September with a single peak in August. The average annual rainfall total is about $850 \mathrm{~mm}$. The concentration of rain in these three months (July to September) has the potential of increasing the soil moisture condition, reducing infiltration capacity and hence causing flooding (Abashiya et al., 2017). The mean maximum monthly temperature is about $35^{\circ} \mathrm{C}$ while the mean minimum monthly temperature is about $18^{\circ} \mathrm{C}$ with relative humidity of about $95 \%$ in August.

The study area forms part of the sedimentary Upper Benue trough, which is structurally controlled by preexisting Basement Complex rock consisting of granitic rocks overlain by the sequence of folded Cretaceous sedimentary rocks. These Basement Complex rocks are mainly fine-coarse-grained porphyritic older granites, gneiss, migmatite, gabbros and diorite (Carter et al, 1963; Obaje, 2009). The bedrock mainly consists of sandstones of cretaceous age, covered by tertiary and quartenary deposits (Obaje, 2009).

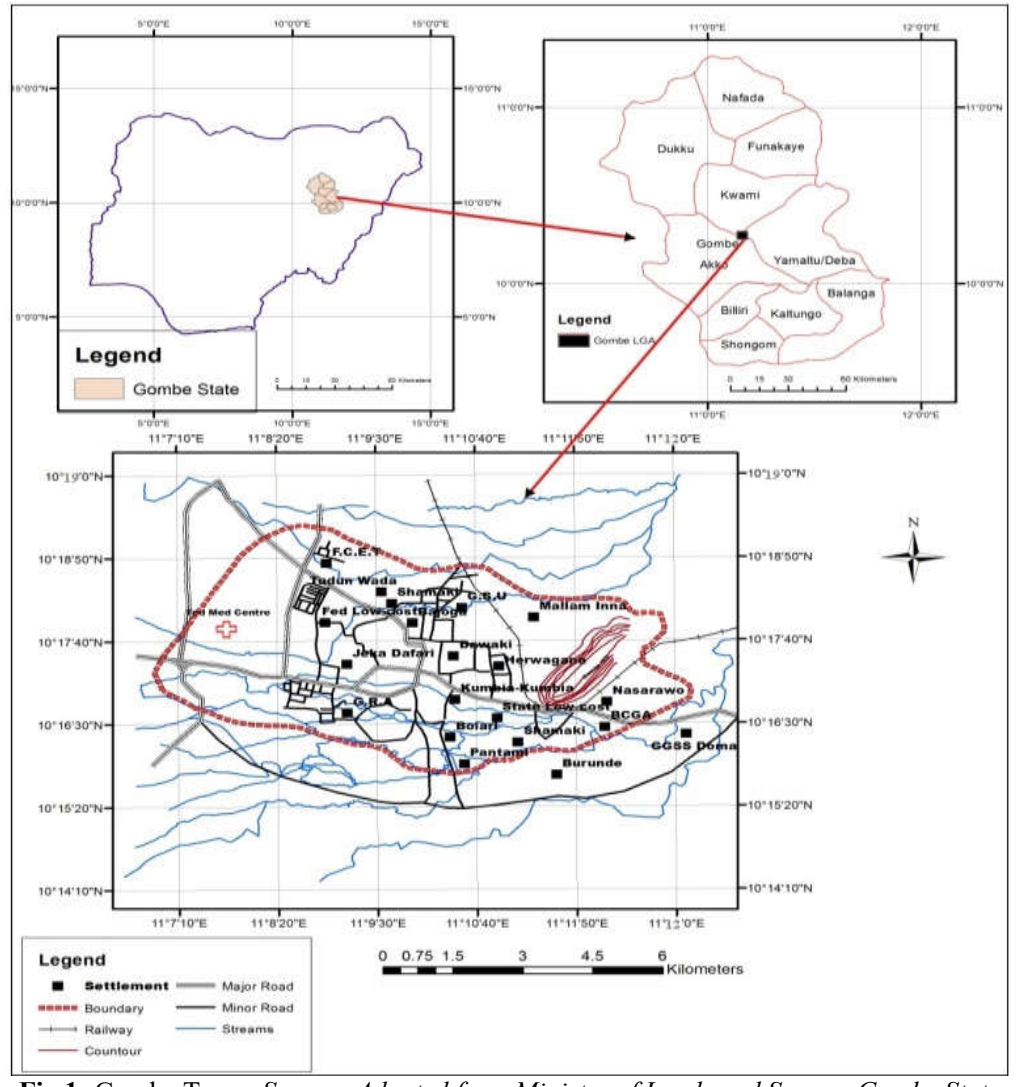

Fig 1: Gombe Town. Source: Adapted from Ministry of Lands and Survey, Gombe State

The soils are formed from the intensive weathering of the Basement Complex rocks. They consists of unconsolidated wind-blown or water deposited sand and clay-rich mostly in the southeast of the town along the valley of Pantami catchment (Orazulike, 1992). Soil nutrients except aluminium and iron decrease substantially, this gives the ferric red soils or the KerriKerri formation that have lost the topsoil organic 
matter (Amos, Musa, Abashiya and Abaje, 2015). This is attributed to traditional agricultural practices such as slash and burn over the years that has made the soils susceptible to soil erosion which reduced the water holding capacity and increase in surface water flow leading to pluvial flooding. These soils that have been subjected to degradation are mostly nitosols, leptosols, cambisols, or luvisols (Ikusemoran, Didams and Abashiya, 2018). The vegetation is the Sudan savannah type which has replaced the guinea savannah of the 1970s due to anthropogenic activities and climate change with many tree species becoming extinct (Mbaya, 2016).

Data Collection and Analysis: The moisture condition of the area prior to storm runoff was calculated using the API. The API for any day is computed as:

$$
A P I=K P_{1}+K P_{2}+K P_{3} \ldots \ldots . K P_{n}
$$

Where: $P_{1} P_{2} P_{3} \ldots \ldots P_{n}=$ rainfall amount $(\mathrm{mm})$ at different days preceding the storm event, $K_{1}, K_{2}, K_{3} \ldots \ldots K_{n}=$ a constant uniformly taken as 0.92 (Bruce and Clark, 1975).

Some storm events were monitored in 2014 to observe the influence of rainfall, stream discharge and antecedent precipitation index on flooding. The velocity-area technique of measuring stream discharge was used, since weirs structures were not possible but rather a graduated bridge-pier along the Pantami catchment and a staff gauge were used to gauge the stage heights. The stream discharge is the direct function of velocity and cross-sectional area of the stream at the point of measurement, given by Gregory and Walling (1973) as:

$Q=A V$

Where: $Q=$ is the stream discharge in cumecs; $A=$ is the cross sectional area in $\mathrm{km}^{2} ; V=$ is the velocity in $\mathrm{m} / \mathrm{s}$

The cross-sectional area of the channel at the gauging station was determined by multiplying the channel width by depth. The relevant depth is that measured from water level to the bottom of the channel using a staff gauge. The stream velocity was also determined using the current meter obtained from the department of Geography Gombe State University, Gombe. The flow accumulation map was generated from the flow direction map using a weight factor in ArcGIS environment. The accumulated flow is based on the number of cells flowing into each cell in the output raster. The drainage density is inversely proportional to permeability. The drainage pattern of a place plays a geomorphic role in assessing the hydrological condition and hence enhances the understanding of its influence on flood. The higher the drainage density the higher the runoff and is given by the total stream length per area $\left(\mathrm{km} / \mathrm{km}^{2}\right)$. The drainage network was extracted from DEM and the density map was generated in the ArcGIS 10.5. DEM hydro analysis was then carried out from the ArcGIS 10.5 Software to produce slope map and drainage density map of the study area. Slope map of the study area was developed using two Digital Elevation Model DEM for the study comprising of Shuttle Radar Topographic Mission (SRTM) Version 3 commonly referred to as SRTM DEM (90m) and Aster DEM (30m) data obtained from the NASA's website and National Centre for Remote Sensing Jos were used to provide the most recent elevation information of the study area using Arc GIS 10.5 software.

\section{RESULTS AND DISCUSSION}

Hydrological Characteristics of Gombe Town: The result of some hydrological characteristics of Gombe town monitored for the year 2014 is presented in Table 1. A total of 45 storms were monitored during the 2014 rainy season from June to September which conformed with the pattern of rainfall observed in the study area that gradually stabilizes from mid- June and soil moisture condition is also at its peak between June and early September (Tarhule and Woo, 1998). The results show that the least API of $18.12 \mathrm{~mm}$ occurred on the $18 / 6 / 2014$. The rainfall amount was $1.2 \mathrm{~mm}$ for 62 minutes, average rainfall intensity was 1.16 , stage height $(0.30 \mathrm{~m})$, average flow velocity $(0.24 \mathrm{~m} / \mathrm{s})$, and instantaneous discharge of $0.49 \mathrm{~m}^{3} / \mathrm{s}$. The highest API of $166.62 \mathrm{~mm}$ on the other hand occurred on the $5 / 9 / 2014$. The rainfall amount was $92.5 \mathrm{~mm}$ for a duration 48 minutes, average rainfall intensity was 115.63 , stage height $(1.42 \mathrm{~m})$, average flow velocity $(0.98 \mathrm{~m} / \mathrm{s})$, and instantaneous discharge of $9.47 \mathrm{~m}^{3} / \mathrm{s}$. The highest recorded rainfall of $92.5 \mathrm{~mm}$ that lasted for 48 minutes given the highest intensity of 115.63 and the highest gauge height of $1.42 \mathrm{~m}$, correspond with the flood disaster that occurred in Gombe town on the $5 / 9 / 2014$. Prior to this date, there were four rainfall storms that occurred on the $25 / 8 / 2014,29 / 8 / 2014$, $2 / 9 / 2014$, and $3 / 9 / 2014$ with rainfall amount of 35.8 $\mathrm{mm}, 34.4 \mathrm{~mm}, 12.5 \mathrm{~mm}$, and $14.6 \mathrm{~mm}$ respectively. This total amount of rainfall $(97.3 \mathrm{~mm})$ must have increase the soil moisture condition. When this amount of rainfall is added to the $92.5 \mathrm{~mm}$ that occurred on the $5 / 9 / 2014$, it means that a total of 189.8 $\mathrm{mm}$ of rainfall was recorded in just five storms events. 
Table 1: Some hydrological Characteristics of Gombe Town (2014). Source: Authors' Fieldwork (2014)

\begin{tabular}{|c|c|c|c|c|c|c|c|c|c|}
\hline S/No & Date & $\begin{array}{l}\text { Mean } \\
\text { Daily } \\
\text { Rainfall } \\
(\mathrm{mm})\end{array}$ & $\begin{array}{l}\text { Rainfall } \\
\text { Duration } \\
\text { (minutes) }\end{array}$ & $\begin{array}{l}\text { Average } \\
\text { Rainfall } \\
\text { Intensity }\end{array}$ & $\begin{array}{l}\text { Stage } \\
\text { Height } \\
\text { (m) }\end{array}$ & $\begin{array}{l}\text { Mean } \\
\text { Velocity } \\
(\mathrm{m} / \mathrm{s})\end{array}$ & $\begin{array}{l}\text { Cross- } \\
\text { Sectional } \\
\text { Area }\left(\mathbf{m}^{2}\right)\end{array}$ & $\begin{array}{l}\text { Instantaneous } \\
\text { Discharges }\left(\mathrm{m}^{3} / \mathrm{s}\right)\end{array}$ & $\begin{array}{l}\text { API } \\
(\mathbf{m m})\end{array}$ \\
\hline 1 & $2 / 6 / 14$ & 40.6 & 38 & 64.11 & 0.94 & 0.73 & 6.39 & 4.67 & 37.35 \\
\hline 2 & $6 / 6 / 14$ & 5.6 & 45 & 7.47 & 0.34 & 0.26 & 2.31 & 0.60 & 32.53 \\
\hline 3 & $10 / 6 / 14$ & 9.8 & 70 & 8.40 & 0.63 & 0.47 & 4.28 & 2.01 & 32.98 \\
\hline 4 & $18 / 6 / 14$ & 1.2 & 62 & 1.16 & 0.30 & 0.24 & 2.04 & 0.49 & 18.12 \\
\hline 5 & $21 / 6 / 14$ & 16.5 & 64 & 15.47 & 0.76 & 0.65 & 5.17 & 3.36 & 30.62 \\
\hline 6 & $24 / 6 / 14$ & 4.0 & 52 & 4.62 & 0.36 & 0.25 & 2.45 & 0.61 & 27.85 \\
\hline 7 & $26 / 6 / 14$ & 0.6 & 32 & 1.13 & 0.23 & 0.22 & 1.56 & 0.34 & 24.17 \\
\hline 8 & $27 / 6 / 14$ & 0.7 & 46 & 0.91 & 0.24 & 0.23 & 1.63 & 0.38 & 22.94 \\
\hline 9 & $30 / 6 / 14$ & 9.1 & 68 & 8.03 & 0.66 & 0.56 & 4.49 & 2.51 & 26.97 \\
\hline 10 & $2 / 7 / 14$ & 2.9 & 95 & 1.83 & 0.28 & 0.27 & 1.90 & 0.51 & 25.73 \\
\hline 11 & $5 / 7 / 14$ & 6.1 & 98 & 3,74 & 0.41 & 0.35 & 2.79 & 0.98 & 26.14 \\
\hline 12 & $8 / 7 / 14$ & 72.4 & 78 & 55.69 & 1.24 & 0.78 & 8.43 & 6.58 & 92.76 \\
\hline 13 & 9/7/14 & 1.5 & 54 & 1.67 & 0.34 & 0.28 & 2.31 & 0.65 & 86.84 \\
\hline 14 & $11 / 7 / 14$ & 13.2 & 47 & 16.85 & 0.42 & 0.32 & 2.86 & 0.92 & 86.70 \\
\hline 15 & $16 / 7 / 14$ & 5.6 & 35 & 9.60 & 0.32 & 0.26 & 2.18 & 0.57 & 62.74 \\
\hline 16 & $18 / 7 / 14$ & 82.0 & 93 & 52.90 & 1.38 & 0.82 & 9.38 & 7.69 & 135.1 \\
\hline 17 & $21 / 7 / 14$ & 8.5 & 25 & 20.40 & 0.56 & 0.43 & 3.81 & 1.64 & 113.7 \\
\hline 18 & $28 / 7 / 14$ & 10.8 & 28 & 23.14 & 0.36 & 0.25 & 2.45 & 0.61 & 74.23 \\
\hline 19 & $30 / 7 / 14$ & 12.1 & 41 & 17.71 & 0.48 & 0.34 & 3.26 & 1.11 & 80.39 \\
\hline 20 & $30 / 7 / 14$ & 0.8 & 32 & 1.50 & 0.26 & 0.21 & 1.77 & 0.37 & 74.76 \\
\hline 21 & $31 / 7 / 14$ & 11.5 & 80 & 8.63 & 0.46 & 0.33 & 3.13 & 1.03 & 80.28 \\
\hline 22 & $3 / 8 / 14$ & 5.5 & 34 & 9.71 & 0.32 & 0.24 & 2.18 & 0.52 & 68.01 \\
\hline 23 & $11 / 8 / 14$ & 26.0 & 75 & 20.80 & 0.72 & 0.76 & 4.90 & 3.72 & 60.90 \\
\hline 24 & $14 / 8 / 14$ & 13.2 & 64 & 12.38 & 0.47 & 0.37 & 3.20 & 1.18 & 50.63 \\
\hline 25 & $15 / 8 / 14$ & 10.7 & 26 & 24.69 & 0.58 & 0.46 & 3.94 & 1.81 & 57.28 \\
\hline 26 & $16 / 8 / 14$ & 5.2 & 45 & 6.93 & 0.34 & 0.26 & 2.31 & 0.60 & 57.90 \\
\hline 27 & $18 / 8 / 14$ & 6.2 & 68 & 5.47 & 0.38 & 0.28 & 2.58 & 0.72 & 55.21 \\
\hline 28 & $19 / 8 / 14$ & 5.5 & 62 & 5.32 & 0.31 & 0.24 & 2.11 & 0.51 & 56.29 \\
\hline 29 & $20 / 8 / 14$ & 0.9 & 46 & 1.17 & 0.27 & 0.23 & 1.84 & 0.42 & 52.69 \\
\hline 30 & $21 / 8 / 14$ & 6.6 & 58 & 6.83 & 0.39 & 0.27 & 2.65 & 0.72 & 55.08 \\
\hline 31 & $22 / 8 / 14$ & 8.9 & 35 & 15.26 & 0.43 & 0.38 & 2.92 & 1.11 & 59.57 \\
\hline 32 & $25 / 8 / 14$ & 35.8 & 67 & 32.84 & 0.80 & 0.73 & 5.58 & 4.07 & 82.19 \\
\hline 33 & $29 / 8 / 14$ & 34.4 & 61 & 33.84 & 0.80 & 0.72 & 5.44 & 3.92 & 93.28 \\
\hline 34 & 2/9/14 & 12.5 & 36 & 20.83 & 0.46 & 0.33 & 3.13 & 1.03 & 79.32 \\
\hline 35 & $3 / 9 / 14$ & 14.6 & 91 & 9.63 & 0.49 & 0.34 & 3.33 & 1.13 & 87.57 \\
\hline 36 & $5 / 9 / 14$ & 92.5 & 48 & 115.63 & 1.42 & 0.98 & 9.66 & 9.47 & 166.6 \\
\hline 37 & $7 / 9 / 14$ & 1.1 & 25 & 2.64 & 0.31 & 0.24 & 2.11 & 0.51 & 142.1 \\
\hline 38 & $13 / 9 / 14$ & 35.4 & 46 & 46.17 & 1.12 & 0.76 & 7.62 & 5.79 & 121.5 \\
\hline 39 & $15 / 9 / 14$ & 2.2 & 32 & 4.13 & 0.28 & 0.21 & $1 / 90$ & 0.40 & 105.1 \\
\hline 40 & $16 / 9 / 14$ & 2.6 & 71 & 2.20 & 0.29 & 0.20 & 1.97 & 0.39 & 99.30 \\
\hline 41 & $20 / 9 / 14$ & 15.1 & 58 & 15.62 & 0.54 & 0.41 & 3.67 & 1.51 & 86.24 \\
\hline 42 & $21 / 9 / 14$ & 29.2 & 92 & 19.04 & 0.76 & 0.69 & 5.17 & 3.57 & 108.5 \\
\hline 43 & $22 / 9 / 14$ & 9.6 & 43 & 13.40 & 0.65 & 0.52 & 4.42 & 2.30 & 109.4 \\
\hline 44 & $27 / 9 / 14$ & 15.8 & 69 & 13.74 & 0.68 & 0.48 & 4.62 & 2.22 & 87.94 \\
\hline 45 & $29 / 9 / 14$ & 41.5 & 59 & 42.20 & 0.96 & 0.74 & 6.53 & 4.83 & 116.1 \\
\hline
\end{tabular}

Flow Accumulation: The flow accumulation map of Gombe town is presented in Figure 2. The result of flow accumulation is a raster of accumulated flow to each cell, as determined by accumulating the weight for all cells that flow into each downslope cell. While output cells with high flow accumulation constitute areas of concentrated flow that can be used to identify drainage channels, output cells with a flow accumulation of very low to zero are local topographic highs that can be used to identify ridges. The Flow accumulation operation determines the number of pixels that naturally drain into outlets. The operation can be used to find the drainage pattern of a terrain.
Drainage Density: The drainage density map of Gombe town is presented in Figure 3. The drainage density of a geographical area has an inverse relationship with permeability; the higher the drainage density the lesser the amount of infiltration which increases the amount of runoff leading to flooding. In the study area, the drainage density varies from $0.00 \mathrm{~km} / \mathrm{km}^{2}$ to $0.54 \mathrm{~km} / \mathrm{km}^{2}$ (total length of the drainages per $\mathrm{km}^{2}$ ). There are six classes in the drainage density and the highest class with $0.54-0.43$ $\mathrm{km} / \mathrm{km}^{2}$ or $36 \%$ is the most significant in terms of runoff generation and triggering of flooding while lowest class with $0.09-0.00 \mathrm{~km} / \mathrm{km}^{2}$ or $5 \%$ is the least significant for runoff contribution. 


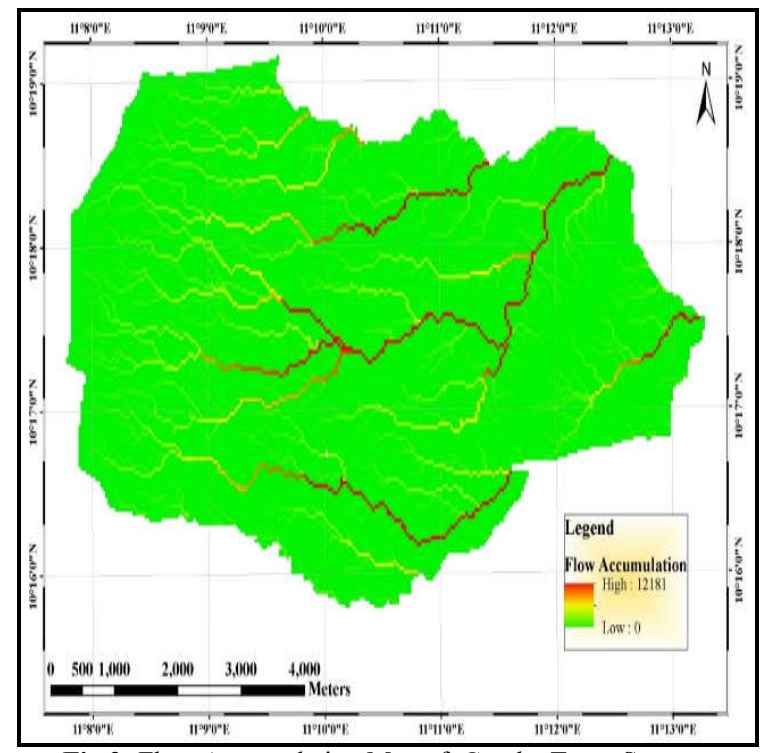

Fig 2: Flow Accumulation Map of Gombe Town Source: Authors' GIS Analysis (2016)

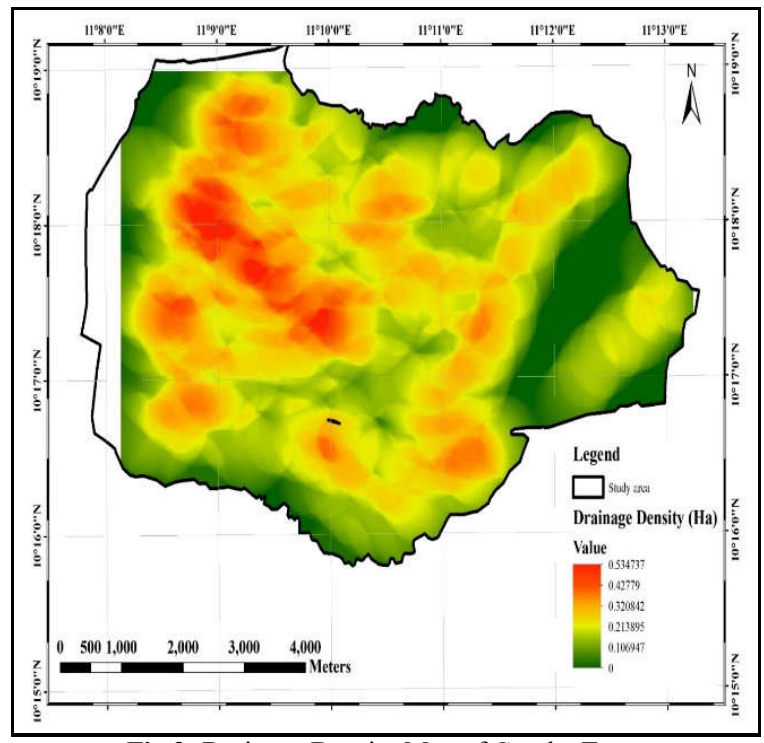

Fig 3: Drainage Density Map of Gombe Town Source: Authors' GIS Analysis (2016)

Slope Morphology: Figure 4 shows the slope morphology map of Gombe town which has five classes namely: very steep, steep, moderate, gentle and flat. Their areas and percentages were also calculated using ArcGIS 10.2 software tool convertor. The results show that very steep slope covered an area of $2.4537 \mathrm{~km}^{2}$ or $1.78 \%$, steep slope $\left(3.60235 \mathrm{~km}^{2}\right.$ or $2.61 \%)$, moderate slope $\left(0.735574 \mathrm{~km}^{2}\right.$ or $\left.0.53 \%\right)$, gentle slope $\left(131.106 \mathrm{~km}^{2}\right.$ or $\left.94.89 \%\right)$ and flat areas $\left(0.259854 \mathrm{~km}^{2}\right.$ or $\left.0.19 \%\right)$. The slope is the ratio of runoff to infiltration with inverse relationship. It is the change in height verses change in horizontal distance. Hence the steeper the slope the greater the runoff and the lower the infiltration. The result indicates that gentle slope has the highest area of $131.106 \mathrm{~km} 2$ or $94.89 \%$ and flat areas have the least $0.25985 \mathrm{~km} 2$ or $0.19 \%$. These two areas occupy a total of $131.36585 \mathrm{~km}^{2}$ or $95.08 \%$. This implies that $95.08 \%$ of Gombe town is low lying. These are areas that are more liable to flooding because of low velocity of runoff, flow water finding its way to the streams ponding and water-logging causing urban flooding.

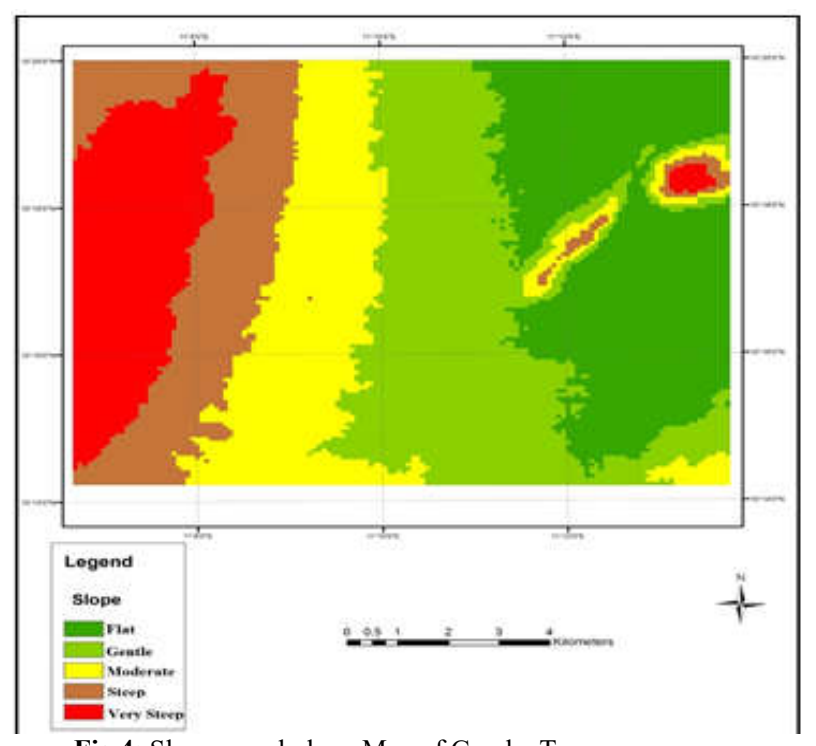

Fig 4: Slope morphology Map of Gombe Town

Source: Authors' GIS Analysis (2016)

Conclusion: Urban flooding occurs in response to intense rainfall which overwhelms natural or manmade inadequate drainage systems resulting in water flowing overland and ponding in depressions. The results of the study revealed that initial soil moisture condition, rainfall amount, intensity and duration, drainage density and topographical characteristics are crucial factors that trigger urban flooding. Observation of the API show a rhythm which followed the rainfall regime of the area during the period of study.This study recommends proper flood resilience technology and urban storm water management. Besides structural measures aiming at a reduction of the probability of flooding, the adoption of non-structural approaches for urban flood mitigation is important. Urban planning guidelines and flood management strategies should, therefore, be part of an integral approach to the problem of flooding for any appropriate authority concerned in Gombe State such as Gombe State Ministry of Lands and Survey and Urban Town Planners.

\section{REFERENCES}

Abaje, IB; Abashiya, M; Onu, V; Masugari, DY (2017). Climate Change Impact and Adaptation 
Framework for Rural Communities in Northern Nigeria. Journal of Research in National Development (JORIND), 15 (2): 142-150.

Abaje, IB; Ati, OF; Iguisi, EO (2012). Changing Climatic Scenarios and Strategies for Drought Adaptation and Mitigation in the SudanoSahelian Ecological Zone of Nigeria. In: Iliya, M.A., and Dankani, I.M. (eds). Climate Change and Sustainable Development in Nigeria, $99-$ 121. Crown F. Publishers, Ibadan.

Abaje, IB; Ishaya, S; Abashiya, M (2016). Evidence of Global Warming From Statistical Analysis of Temperature Data of Kaduna State, Nigeria.Nigeria Geographical Journal 1(1): 125 140

Abaje, IB; Ogoh, AO; Amos, BB; Abashiya, M (2015). Climate Change, Flood Disaster Assessment and Human Security in Katsina State, Nigeria. American Journal of Human Ecology, 4(4): 47-56.

Abaje, IB; Onu,V; Abashiya, M; Oyatayo, KT; Ibrahim, AA; Ati, OF; Sawa, BA (2017). Climate Change Vulnerability Assessment in the Northern part of Katsina State, Nigera: A quantitative Approach. DUTSE Journal of Pure and Applied Sciences, 3(1): 11-14.

Abashiya, M (2006). Influences of Man-made Structures on Floods in the Northern Parts of Kaduna Metropolis, Nigeria. Unpublished M.Sc. Dissertation, Department of Geography A.B.U. Zaria.

Abashiya, M; Abaje, IB; Iguisi, EO; Bello, AL; Sawa, BA; Amos, BB; Musa, I (2017). Rainfall Characteristics and Occurrence of Floods in Gombe Metropolis, Nigeria. Ethiopian Journal of Environmental Studies and Management, 10(1): 44-54.

Amos, BB; Musa, I; Abashiya, M; Abaje, IB (2015). Impact of Cement Dust Emissions on Soils within $10 \mathrm{~km}$ Radius in Ashaka Area, Gombe State, Nigeria. International Journal of Environment and Pollution. 4(1): 0909-0917.

Bruce, JP; Clark, RH (1975). Introduction to Hydrometeorology. Pergamon Press, OxfordLondon.
Carter, J D; Barber, W; Tait, EA; Jones, GP (1963). The Geology of Parts of Adamawa, Bauchi and Borno Provinces in Northern Nigeria. Bull. 30, $108 p p$.

Duan, W; He, B; Nover, D; Fan, J; Yang, G; Chen, W; Meng, H; Liu, C (2016). Floods and Associated Socioeconomic Damages in China over the Last Century. Natural Hazards, 1-13.

Goudie, A (2006). Global Warming and Fluvial Geomorphology. Journal of Geomorphology 79: 3-4.

Gregory, KJ; Walling, DE (1973). Drainage Basin Form and Processes: A Geomorphological Approach. Edward Arnold Publishers Ltd, London.

Ikusemoran, M; Didams, G; Abashiya, M (2018). Analysis of the Spatial Distributions of the Geology and Pedologic Formations in Gombe State, Northeastern Nigeria. Journal of Geology and Geography, 10(1): 1916-9779.

IPCC (2013). Climate Change 2013: The Physical Science Basis. Contribution of Working Group I to the Fifth Assessment Report of the IPCC. Cambridge University Press, Cambridge, United Kingdom and New York, NY, USA.

Mbaya, LA (2016). Climate Change Induced Tree Mortality in the Savanna Woodland and its Implication on Rural Livelihoods in Gombe State, Nigeria. Nigerian Journal of Tropical Geography, 7(1): 952-968.

Obaje, NG (2009). Geology and Mineral Resources of Nigeria. Springer Publishers, Dordrecht Heidelberg, pp 65-68.

Orazulike, DM (1992). A Study of the Gully Phenomenon in Gombe Town, Bauchi State: Bedrock Geology and Environmental Implications. Natural Hazards, 5: 199-203.

Tarhule, A; Woo, M (1998). Changes in Rainfall Characteristics of Northern Nigeria. International Journal of Climatology, 18: 12611271. 